General Thoracic: Controversies in the Utilization of New Technology

Chairmen: Shaf Keshavjee, MD, MSc, Toronto General Hospital

Thomas A. D'Amico, MD, Duke University

Congenital Chair: Christopher A. Caldarone, MD, The Hospital for Sick Children

Endobronchial Ultrasound Training Course

Chairmen: Shaf Keshavjee, MD, MSc, Toronto General

Hospital

Andrew Pierre, MD, University of Toronto

Kazuhiro Yasufuku, MD, University of Toronto

Visit www.aats.org for updates.

\section{Aortic Symposium 2010}

April 29-30, 2010

Sheraton New York Hotel and Towers

New York, New York

Course Directors:

Randall B. Griepp, MD

Mount Sinai School of Medicine

Steven L. Lansman, MD, PhD

Westchester Medical Center

\section{Co-Directors:}

Joseph E. Bavaria, MD

University of Pennsylvania

Nicholas T. Kouchoukos, MD

Missouri Baptist Medical Center

David Spielvogel, MD

Westchester Medical Center

\section{Program Overview:}

Aortic Symposium 2010 is a two-day symposium focused on the pathophysiology, diagnosis, and treatment of aortic aneurysms and dissections. This conference is designed for cardiovascular and thoracic surgeons, residents, perfusionists, ICU and OR nurses, and those involved with the care of individuals with aortic disease. The faculty consists of world leaders in this field who have been invited to share their experience regarding difficult problems in aortic disease.

\section{Call for Abstracts:}

Log on to www.aats.org/aortic and select Abstract/Video submission link. Specific instructions for abstract/video submission are located on the submission Web site, including how to submit graphs and charts.

Authors submitting abstracts/videos for Aortic Symposium 2010 must use electronic submission ONLY.
Abstracts/Videos must be received by Friday, December 11, 2009, by 11:59 PM Eastern Standard Time.

Visit www.aats.org/aortic to learn more about Aortic Symposium 2010.

\section{AATS Meetings and Sponsored Events}

\section{February}

February 6-9, 2010

The 10th Annual International Symposium on

Congenital Heart Disease

Renaissance Vinoy Resort

St Petersburg, Florida, USA

February 27, 2010

AATS/ASCVTS/IACTS Postgraduate Course

The Ashok

New Delhi, India

March

March 21-26, 2010

15th Annual Update on Cardiopulmonary Bypass

Fairmont Chateau

Whister, BC, Canada

April

April 29-30, 2010

Aortic Symposium 2010

Sheraton New York Hotel and Towers

New York City, New York, USA

May

May 1-5, 2010

AATS 90th Annual Meeting

Metro Toronto Convention Centre

Toronto, Ontario, Canada

May 30, 2010

AATS/ESTS/STS Postgraduate Course

Feria de Valladolid

Valladolid, Spain

\section{Ocotber}

October 21-22, 2010

21st Century Treatment of Heart Failure 2010

The InterContinental Hotel and Bank of America Conference Center

Cleveland, Ohio, USA

\section{Summer Intern Scholarship Applications Now Available}

The American Association for Thoracic Surgery (AATS) Summer Intern Scholarship program introduces the field of cardiothoracic surgery to first- and second-year medical 